\title{
Leiden Journal of International Law
}

\author{
Instructions for contributors
}

EDITORIAL POLICY

Leiden Journal of International Law is firmly established as one of Europe's leading journals in the field. It provides a forum for two vital areas, namely international legal theory and international dispute settlement. It is unique in providing the most comprehensive coverage of the world's most important international tribunals in The Hague and elsewhere (such as the ICJ, ICTY, ICC and others), as well as examining new trends in international legal thinking. LJIL is essential reading for academics and practitioners who need to stay abreast of recent developments.

Only articles which fall within the scope of the journal will be considered for publication.

\section{SUBMISSIONS}

Articles in good English to be considered for publication should be submitted online at http://mc. manuscriptcentral.com/ljil. More information can be found at the editors' website www.grotiuscentre. org (under LJIL)

Submission of a paper will be taken to imply that neither the article as a whole, nor any substantial part of it, has been published previously nor is it being considered for publication elsewhere. Upon acceptance of a paper, the authors will be asked to assign copyright to the Foundation of the Leiden Journal of International Law.

Contributors are responsible for obtaining permission to reproduce any materials, including photographs and illustrations for which they do not hold copyright, and for ensuring that the appropriate acknowledgements are included in the manuscript.

All contributions to $L J I L$ are peer-reviewed.

\section{MANUSCRIPT PREPARATION}

The Editors recommend the following word counts for the journal's sections: Articles up to Io,ooo words; Hague International Tribunals and Current Legal Developments up to 8,000 words; Book Review Essays up to 5,000; and Book Reviews up to I,500 words.

\section{PROCEDURES}

After receipt, the contribution will be sent for peer review. If the article is considered eligible for publication, any revisions deemed necessary will be sent to the author. The author will be given three weeks to make the necessary changes.

\section{TEXT CONVENTIONS}

Copy-editing can be a lengthy and complex business, so it is essential that contributors observe the LJIL's text conventions closely. Typescripts which do not may be returned for amendment. Contributions should refer to the LJIL's rules of citation and points of style, which can be found at http://assets.cambridge.org/LJL/ljl_ifc.pdf

\section{PROOFS}

Proofs may be expected about three months before publication. Only essential typographical or factual errors may be changed at proof stage. Resist the temptation to revise or add to the text. The publisher reserves the right to charge authors for correction of non-typographical errors.

\section{OFFPRINTS}

Authors of articles, review essays and book reviews will receive a pdf file of their contribution and a complimentary issue upon publication. Offprints can be purchased if the form is completed and returned to the publisher on receipt of the first proofs. 


\section{Leiden journal \\ of international Law}

\section{Contents}

25 I Editorial: Between 'Faith' and 'Facts': By What Standards Should We Assess International Criminal Justice? Carsten Stahn INTERNATIONAL LEGAL THEORY

283 Standardization: A Dynamic and Procedural Conceptualization of International Law-Making Yannick Radi SYMPOSIUM ON SOFT LAW

309 Which Future for the Scholarly Concept of Soft International Law? Editors' Introductory Remarks Jean d'Aspremont and Tanja Aalberts

313 Shades of Grey: Soft Law and the Validity of Public International Law Jaye Ellis

335 We Need to Cut Off the Head of the King: Past, Present, and Future Approaches to International Soft Law Matthias Goldmann

369 The King Is Dead, Long Live the King? A Reply to Matthias Goldmann Jaye Ellis

373 Soft Law and Other Forms of International Public Authority - The View from Discourse Theory: A Reply to Jaye Ellis Matthias Goldmann

INTERNATIONAL LAW AND PRACTICE Symposium: Fairness in International Environmental Law

379 Against Fairness? International Environmental Law, Disciplinary Bias, and Pareto Justice Mario Prost and Alejandra Torres Camprubí

397 Extraterritorial Exercise of Jurisdiction for Environmental Protection: Addressing Fairness Concerns Jaye Ellis

4I5 Fairness and International Environmental Law from Below: Social Movements and Legal Transformation in India Kishan Khoday and Usha Natarajan

443 Transnational Conservation Contracts Natasha Affolder HAGUE INTERNATIONAL TRIBUNALS International Court of Justice Symposium : The Nicaragua Case 25 Years Later

46I The Notion of 'Armed Attack' in the Nicaragua Judgment and Its Influence on Subsequent Case Law Judge Abdulqawi A. Yusuf

47 I Jurisdiction and Applicable Law James $R$. Crawford

48 I The Nicaragua Case: 'Mafiosi's' and 'Veteran's' Approaches Combined Alain Pellet

International Criminal Court and Tribunals

49I The Legitimacy of International Criminal Tribunals and the Current Prospects of International Criminal Justice Antonio Cassese

503 Personal Remarks on Antonio Cassese and His Vision of International Law and International Criminal Justice along the Road He Walked Salvatore Zappala

5I I The Appeals Decision in the ICC's Jean-Pierre Bemba Gombo Case on the Trial Chamber's 'Decision on the Admission into Evidence of Materials Contained in the Prosecution's List of Evidence' Christine Schuon

52 I Responsibility of the Netherlands for the Acts of Dutchbat in Nuhanović and Mustafić: The Continuous Quest for a Tangible Meaning for 'Effective Control' in the Context of Peacekeeping Bérénice Boutin

BIBLIOGRAPHY

537 Books and Articles in the Field of the Prevention and Peaceful Settlement of International Disputes (Winter 20I2) Ingrid Kost REVIEW ESSAY

543 The Limits of Legal Pluralism Tom de Boer BOOK REVIEWS

557 Guy S. Goodwin-Gill and Hélène Lambert (eds.), The Limits of Transnational Law: Refugee Law, Policy Harmonization and Judicial Dialogue in the European Union Bríd Ní Ghráinne

56 I Michelle L. Burgis, Boundaries of Discourse in the International Court of Justice: Mapping Arguments in Arab Territorial Disputes Victor Kattan

564 Antonios Tzanakopoulos, Disobeying the Security Council: Countermeasures against Wrongful Sanctions Thomas Liefländer

570 Alice Edwards, Violence against Women under International Human Rights Law Alexandra Timmer

Cambridge Journals Online For further information about this journal please go to the journal website at: journals.cambridge.org/ljl

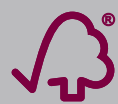

FSC www.fsc.org
MIX

Paper from responsible sources FSC ${ }^{\circ} 018127$
CAMBRIDGE UNIVERSITY PRESS 